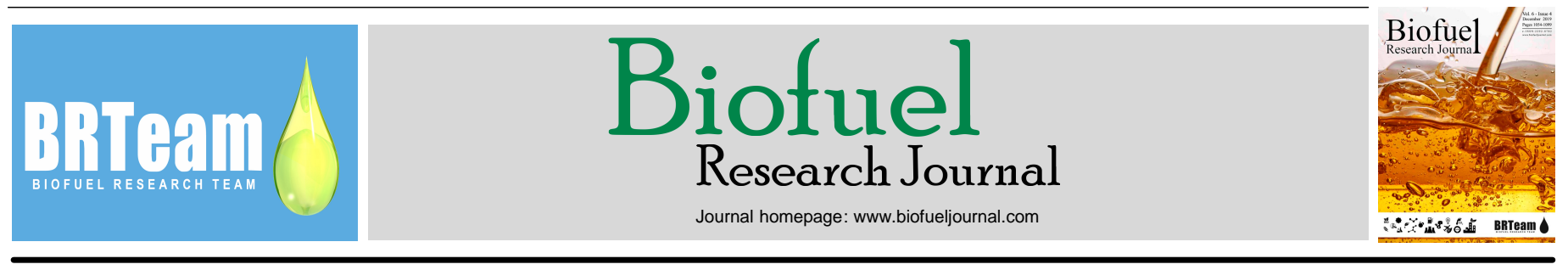

Original Research Paper

\title{
Bio-oil yield and quality enhancement through fast pyrolysis and fractional condensation concepts
}

\author{
Brenda J. Álvarez-Chávez ${ }^{1,2, *}$, Stéphane Godbout ${ }^{2}$, Étienne Le Roux ${ }^{2}$, Joahnn H. Palacios ${ }^{2}$, Vijaya Raghavan ${ }^{1}$
}

${ }^{1}$ Faculty of Agricultural and Environmental Sciences, McGill University, Sainte-Anne-de-Bellevue, Canada.

${ }^{2}$ Research and Development Institute for the Agri-Environment (IRDA), Québec, Canada.

\section{HIGHLIGHTS}

$>$ Pyrolysis optimization allows the production of bio-oil with low water content.

$>$ Two liquids were obtained in the condensers separately by fractional condensation.

$>$ Nitrogen flow and temperature of condenser affect the oily phase yield.

$>$ Nitrogen flow affects the moisture in oil due to the shorter vapor residence time.

$>$ Levoglucosan was the most abundant compound in the pyrolytic oil.

\section{GRAPHICAL ABSTRACT}

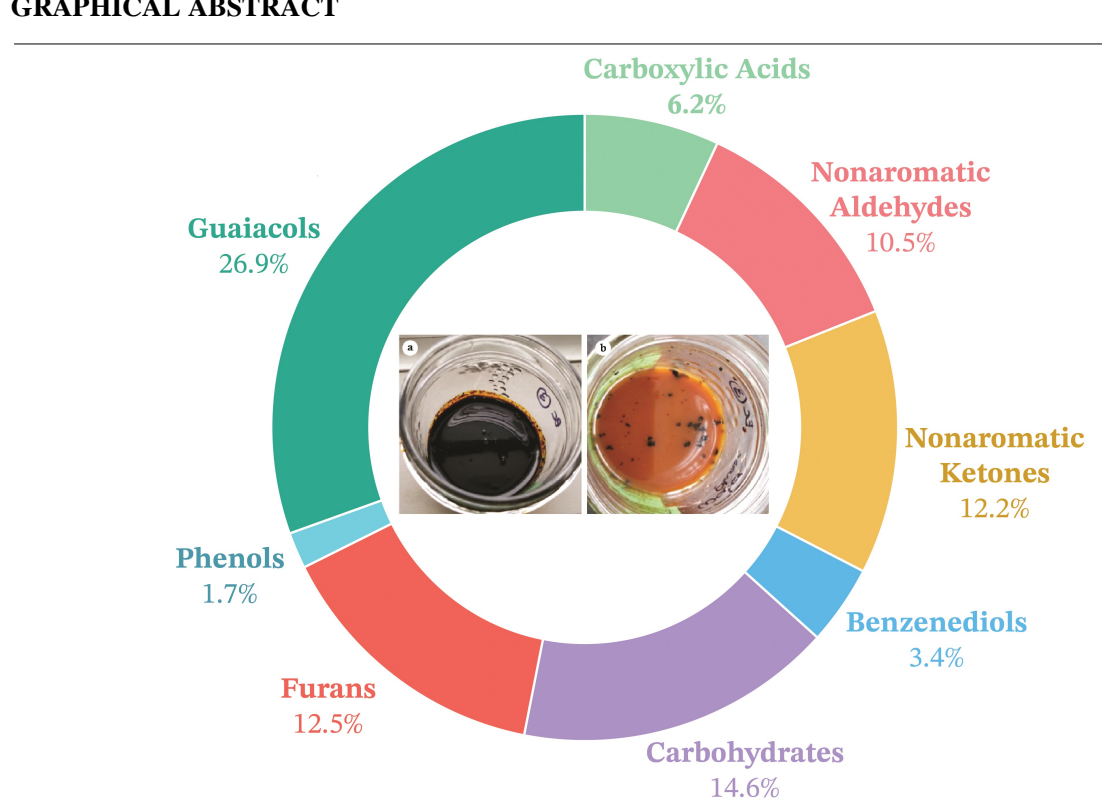

\section{ARTICLE INFO}

\section{Article history:}

Received 14 August 2019

Received in revised form 13 October 2019

Accepted 13 October 2019

Available online 1 December 2019

\section{Keywords:}

Bio-oil

Forest biomass

Fast pyrolysis

Fractional condensation

Box-Behnken

\begin{abstract}
The influence of operating conditions on the yield and quality of bio-oil obtained from black spruce wood mixture was studied using an auger reactor. Fast pyrolysis optimization through response surface analysis was carried out with four variables: pyrolysis temperature, solids residence time, nitrogen flow, and temperature of first stage of condensation. The optimal conditions obtained for bio-oil production were $555^{\circ} \mathrm{C}, 129 \mathrm{~s}, 6.9 \mathrm{~L} / \mathrm{min}$, and $120^{\circ} \mathrm{C}$, respectively. The product yields were 38.61 wt. \% of biochar, $25.39 \mathrm{wt} . \%$ of liquid, and $36.52 \mathrm{wt} . \%$ of non-condensable gases. Two liquid products were produced at the exit of the two condensers, following the concept of fractional condensation. The oily phase yield recovered in the first condenser was $10.59 \mathrm{wt} . \%$, with a $16.86 \mathrm{wt} . \%$ of moisture content. Physical properties of the oily phase were analyzed and compared with the ASTM standard D7544-12. Qualitative identification of chemical compounds was carried out for the oily phase which helped in pyrolysis optimization for the bio-oil production targeted towards its use as fuel in commercial burners. In addition, the oil produced here is one of the lowest in water and solids content, attributable to the unique feature of auger reactors without the need for additional treatments.
\end{abstract}

(C) 2019 BRTeam. All rights reserved.

* Corresponding author at: Tel.: +1 5147743391

E-mail address: brenda.alvarezchavez@ mail.mcgill.ca

Please cite this article as: Álvarez-Chávez B.J., Godbout S., Le Roux É., Palacios J.H., Raghavan V. Bio-oil yield and quality enhancement through fast pyrolysis and fractional condensation concepts. Biofuel Research Journal 24 (2019) 1054-1064. DOI: 10.18331/BRJ2019.6.4.2 


\section{Introduction}

The growing need to find a substitute for fossil fuels has promoted the development of new technologies for the efficient energetic use of biomass. Pyrolysis has shown increasing potential as a thermochemical process capable of producing bio-oil since the 1980s (Rasul, 2016). This process is carried out in the absence of oxygen to produce non-condensable gases, bio-oil, and biochar. The bio-oil contains about 300 organic compounds, where different functional groups such as organic acids, ketones, aldehydes, esters, phenols, furans, and anhydrous sugars can be found (Pittman et al., 2012; Ren et al., 2016). Pyrolytic oil can be used for electricity production, heating (Fu et al., 2017; Kalargaris et al., 2017), and chemical extraction (Onorevoli et al., 2017: Vithanage et al., 2017). The production cost per energy unit of pyrolytic biooil is around \$4.04 - \$21.73/GJ (Mirkouei et al., 2017; Treedet and Suntivarakorn, 2018). However, the quality of the bio-oil is limited by its low chemical stability associated with aging, low calorific value, high water content, high viscosity, and high acidity (Carpenter et al., 2014). Therefore, it is necessary to improve the quality of the bio-oil before its use in our daily lives. For heating applications using stationary combustion systems, the bio-oil must comply with the ASTM standard D7544. One of the main parameters established in this standard is the water content in the oil, where $30 \mathrm{wt} . \%$ is the maximum value for its use in industrial and commercial burners. The water content can influence other properties of the oil such as viscosity, calorific value, density, and $\mathrm{pH}$ (Cai et al., 2018), thus these parameters are to be closely monitored.

The quality of bio-oil depends on the raw material and the technology used for pyrolysis. The chemical composition of biomass plays a crucial role in the quality of bio-oil. Cellulose, hemicellulose, and lignin are the sources of the chemical and physicochemical characteristics of bio-oil. During pyrolysis, the cellulose present in the biomass is degraded to form levoglucosan, oligosaccharides, and other glucose compounds (Shen et al., 2015). Hemicellulose forms acetic acid, glycolaldehyde, furfural and 1:4anhydroxylopyranose, among others (Hosoya et al., 2007; Shen et al., 2015). And, lignin is degraded to form the aromatic compounds present in bio-oil, including phenolics and hydrocarbons (Yang, 2007; Shen et al., 2015). While cellulose and hemicellulose produce the highest volatile yield favouring the production of bio-oil, lignin contributes mainly to the formation of biochar (Yang et al., 2007).

The common raw material used in pyrolysis is agroforestry biomass due to its availability and the potential identified on it. According to the Quebec Biomass Inventory Report, Canada (2012-2020 horizon), the largest amount of forest biomass available in Quebec comes mainly from black spruce, with a technical potential of 541,879 anhydrous metric tons (ÉcoRessources, 2012) .

Pyrolysis technologies which have been used to obtain bio-oil include auger reactors, fixed bed, fluidized bed reactors (bubbling, circulating, and spouted) and ablative reactors (vortex and rotating cone) (David and Kopac, 2018; Gao et al., 2018; Auersvald et al., 2019; Ly et al., 2019; Osorio and Chejne, 2019; Wise et al., 2019). Most of the available reactors require a minimum particle size and a moisture content of around $10 \mathrm{wt} . \%$, which increases the cost of processing the biomass prior to pyrolysis. The literature available focuses on reactors that offer opportunities for commercial expansion, such as auger reactors, bubbling fluidized bed reactors, and circulating fluidized bed reactors. (Bridgwater, 2003; Treedet and Suntivarakorn, 2018). In fluidized bed reactors, heat is mainly transferred by conduction, although convection and radiation can also occur (Bridgwater et al., 1999). The residence time of the gases and solids is controlled by a carrier gas used to transport the bed, obtaining a low residence time of the vapors and gases (Oasmaa et al., 2016). Fluidized bed reactors are chosen because of their higher bio-oil potential and their suitability for scaleup (Ly et al., 2018; Treedet and Suntivarakorn, 2018; Park et al., 2019). In auger reactors, heat transfer occurs by conduction when biomass particles are in contact with the heated surfaces of a conveyor screw. The option of using a carrier gas would be to decrease the residence time of solids, which is not a requirement (Oasmaa et al., 2016).

Some of the advantages of using auger reactors for bio-oil production include the use of lower reaction temperatures, less pre-treatment steps applied to the biomass, robustness, simplicity of the reactor, and offers the possibility of built portable units, reducing the cost of transporting the biomass (Puy et al., 2011; Daugaard et al., 2018). Portable auger reactors could be used for the production of less bulky bio-oil on site, where raw biomass is harvested, for subsequent transport of bio-oil to biorefineries (Ingram et al., 2008). Some authors obtained a bio-oil with a water content below $30 \mathrm{wt} . \%$ using an auger reactor in the temperature ranges of $425-500^{\circ} \mathrm{C}$ (Ravindran et al., 2015). Optimization of a pilot auger reactor was carried out with steel shots as a heat carrier without inert carrier gas at $450-475^{\circ} \mathrm{C}$ to obtain bio-oil with a water content of less than 26 wt.\% (Papari et al., 2017). A comparative study was carried out among the auger, the batch, and the fluidized reactor (Nam et al., 2015), which led to the conclusion that the auger and batch reactors showed a higher calorific value in the oil than the one produced by the fluidized bed reactor, although the latter might produce a higher bio-oil yield. Overall, auger reactors have shown advantages over other technologies; however, they have not received the same academic attention compared to fluidized bed reactors. Therefore, further research is needed to focus on establishing the influence of operating conditions on bio-oil yield and quality with the use of auger reactors.

The optimization of a process is normally carried out using the Response Surface Methodology (RSM). This mathematical and statistical technique is applied when the response of interest is affected by different variables. The objective of RSM is to determine the optimal operating conditions of a system, whether to maximize the response, minimize it or reach a specific value (Montgomery, 2017). RSM aims to find a suitable approximation for the relationship among the variables and the response of interest through a polynomial model (Montgomery, 2017). Some studies of fast pyrolysis optimization using different types of reactors have been published. The most commonly evaluated factors are reaction temperature, biomass particle size, and nitrogen flow. Generally, only the yield of the oil is analyzed as a response of interest, leaving aside the water content and chemical composition of the oil (Abnisa et al., 2011; Ellens and Brown, 2012; Kilic et al., 2014). In addition, the study of the condensation system, through fractional condensation technique is not included as part of the biooil production in most of the published works.

Fractional condensation is an upgrading technique which adjusts the condensing temperature of vapors to separate the bio-oil through dew point differences of condensable components (Gooty et al., 2014). During fractional condensation, the most influencing parameter is the condensing temperature, which significantly affects compound enrichment and composition of bio-oil (Kim et al., 2016; Papari and Hawboldt, 2018). A combination of 2-4 condensers over a wide temperature range has been studied, where the first condenser has usually the highest temperature and the second and third condensers tend to have a lower temperature profile (Westerhof et al., 2007; Westerhof et al., 2011; Pollard et al., 2012; Kim et al., 2014; Kim et al., 2016; Papari and Hawboldt, 2018). It has been observed that using the high temperature-controlled condensers (70$120^{\circ} \mathrm{C}$ ), a fraction of bio-oil with lower water content and higher quantity of organic compounds can be recovered. The remaining fraction, obtained by using low temperature-controlled condensers, contains high water content and light-oxygenated compounds.

According to the literature, there is no study where reactor temperature, residence time of solids in the reactor, as well as nitrogen flow and temperature of the first condenser (fractional condensation) are evaluated simultaneously. Therefore, this study offers the evaluation of four factors that encompass the pyrolysis and condensation system conditions. The objective of the present study was to improve the bio-oil quality reducing the water content, using an auger reactor. The RSM was applied to optimize two independent responses: bio-oil yield and bio-oil moisture content. Four operational variables were studied: reactor temperature, residence time of solids in the reactor, nitrogen flow and temperature of the first condenser. In addition, the properties of the bio-oil were evaluated.

\section{Materials and Methods}

\subsection{Raw materials and sample preparation}

Black spruce biomass used for this study was provided by the Research and Development Institute in Agri-Environment (IRDA). The feedstock was a mixture of wood and bark of black spruce (Picea mariana Mill.). The trees used for this mix were harvested in 2014 in the province of Quebec. Then, the feedstock was stored indoors. Prior to performing the experimental work, black spruce was first crushed and sieved to a particle size between 1.0 and $2.4 \mathrm{~mm}$ and dried at $105^{\circ} \mathrm{C}$ for $12 \mathrm{~h}$. Chemical composition (cellulose, hemicellulose, lignin, soluble extracts, and ash content) of black 
spruce was analyzed by IRDA Lab. Cellulose, hemicellulose, lignin, and soluble extracts were analyzed according to the AFNOR XP U44-162 method. Ash content was analyzed at $500^{\circ} \mathrm{C}$. Results are presented in Table 1 and compared with those from another publication (Pettersen, 1984).

Table 1.

Chemical composition (dry basis) of black spruce used in this study and from a reference.

\begin{tabular}{lcc}
\hline Components (wt.\%) & Black spruce & Wood black spruce (Pettersen, 1984) \\
\hline Cellulose & 35.7 & 44 \\
Hemicellulose & 9.81 & 18.9 \\
Lignin & 31.1 & 30 \\
Soluble extracts & 23.4 & - \\
Ash content & 1.88 & 0.3 \\
\hline
\end{tabular}

\subsection{Pyrolysis system}

A lab-scale auger reactor (Patent CA 2830968), developed by the IRDA in collaboration with the Centre de recherche industriel du Québec (CRIQ), was used for the pyrolysis tests (shown in Fig. 1). The pyrolysis system is located at the IRDA research centre (Deschambault, QC, Canada). This system is also described in other research work (Brassard et al., 2017). The pyrolysis process begins at the hopper, where the biomass is fed to be transported through a horizontal auger with a steel tube diameter of $2.54 \mathrm{~cm}$. The biomass is then fed to the reactor by the $25.4 \mathrm{~cm}$ long vertical auger with a $3.81 \mathrm{~cm}$ thread. The theoretical solid residence time within the pyrolysis reactor was determined as the relationship between the dimensions of the vertical screw conveyor and the speed of the screw. The dwell time of the solids in the reactor is controlled by the rotational speed of both conveyors. The thermal energy was supplied by two $1500 \mathrm{~W}$ heating elements, which surrounds the reaction zone. The reaction temperature is controlled by thermocouples connected to a control panel. Temperature sensors were installed at different positions in the system. Data was collected for each pyrolysis reaction every $10 \mathrm{~s}$ using a data logger (CR10X, Campbell Scientific, Edmonton, AB, Canada). At the exit of the reactor, the biochar was collected by gravity in a specific container $(31.4 \mathrm{~cm}$ high and $16.8 \mathrm{~cm}$ in diameter). The vapors are evacuated to the condensation system using nitrogen as the carrier gas, passing through an internal deflector $(10.2 \mathrm{~cm}$ in diameter and $10.5 \mathrm{~cm}$ in length) to remove the fine particles from the pyrolysis stream. The condensing system includes two condensers. The first condenser is operated with a glycol-water mixture to reach the temperatures

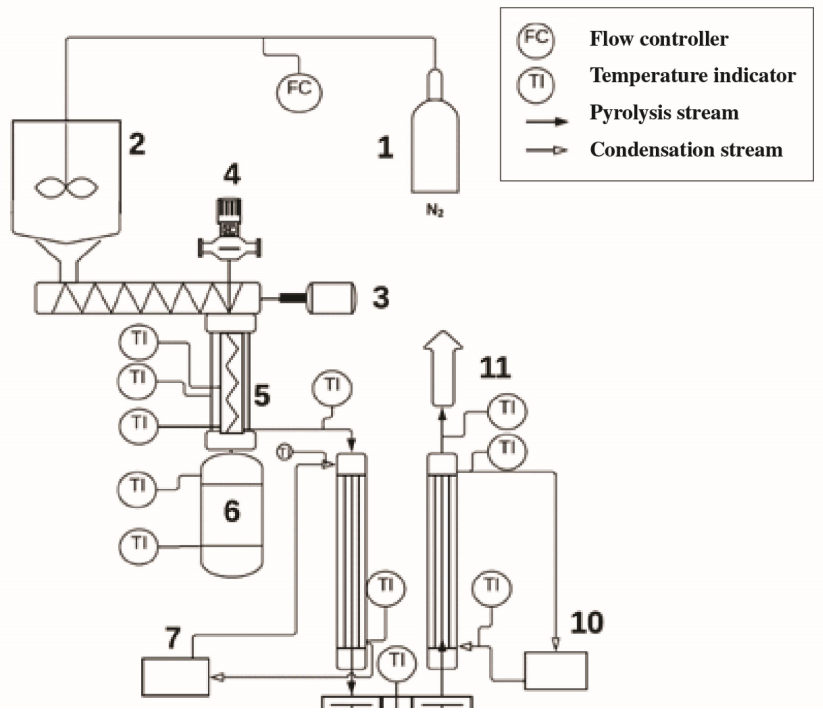

specified by the experimental design, in order to selectively condense the vapors according to their dew points. The oily phase is obtained at the exit of this first condenser. The second condenser is cooled to $4^{\circ} \mathrm{C}$, where an "aqueous phase" is recovered. The nitrogen flow is used as a carrier gas. Before each operation, the air is purged from the system by injecting nitrogen from the hopper for a period of $15 \mathrm{~min}$. The volumetric flow of nitrogen is controlled by a gas flowmeter $(0-25 \mathrm{~L} / \mathrm{min})$.

Specific conditions for pyrolysis tests are established through an experimental design. For each experiment, $500 \mathrm{~g}$ of black spruce is used. The pyrolysis products are named as follows: "oily phase" is the pyrolytic liquid collected by the first condenser; "aqueous phase" is the pyrolytic liquid collected by the second condenser; biochar; and non-condensable gases.

\subsection{Experimental design}

Experimental design for optimization of pyrolysis are performed using the Design Expert software (version 7.0 Stat-Ease Inc. Minneapolis, MN, USA) (Anderson and Whitcomb, 2016). The response surface analysis was based on Box-Behnken Design (BBD), which made it possible to evaluate the effects of the desired responses in order to find the optimal conditions for producing a high yield of the oily phase with low water content. BBD combines $2 \mathrm{k}$ factorials and incomplete block designs, resulting in a very efficient design considering the number of runs and rotation aspect in the design (Montgomery, 2017). The number of runs required $(\mathrm{N})$ were defined by $\mathrm{N}=2 \mathrm{k}(\mathrm{k}-1)+\mathrm{C}_{\mathrm{o}}$, (where $\mathrm{k}$ is the number of factors and $\mathrm{C}_{\mathrm{o}}$ is the number of central points) (Ferreira et al., 2007). The independent factors or variables are: pyrolysis reaction temperature, solids residence time, nitrogen flow, and temperature of the first condenser. Each factor was coded at three levels: $-1,0,+1$, which correspond to the minimum, mean and maximum values, respectively (see Table 2). The selected pyrolysis temperature range was between $400-600^{\circ} \mathrm{C}$, solids residence times between $50-150 \mathrm{~s}$, nitrogen flow between 2.0 and $10.0 \mathrm{~L} / \mathrm{min}$, and temperature in the first condenser between $70-120^{\circ} \mathrm{C}$ using a mixture of glycol and water. The temperature of the second condenser was set at around $4^{\circ} \mathrm{C}$ with an ice bath chiller for each pass. The total number of experiments was 27 , including 3 central points and 24 factorial points. The dependent variables were the yield $\left(\mathrm{Y}_{1}\right)$ and water content $\left(\mathrm{Y}_{2}\right)$ in the bio-oil that came out of the first condenser-oil phase.

\subsection{Oily phase characterization}

The "oily phase" collected at the exit of the first condenser was analyzed. Water content was determined by Karl Fisher titration method. Heating value was determined using a calorimeter (1266 Calorimeter). Solids

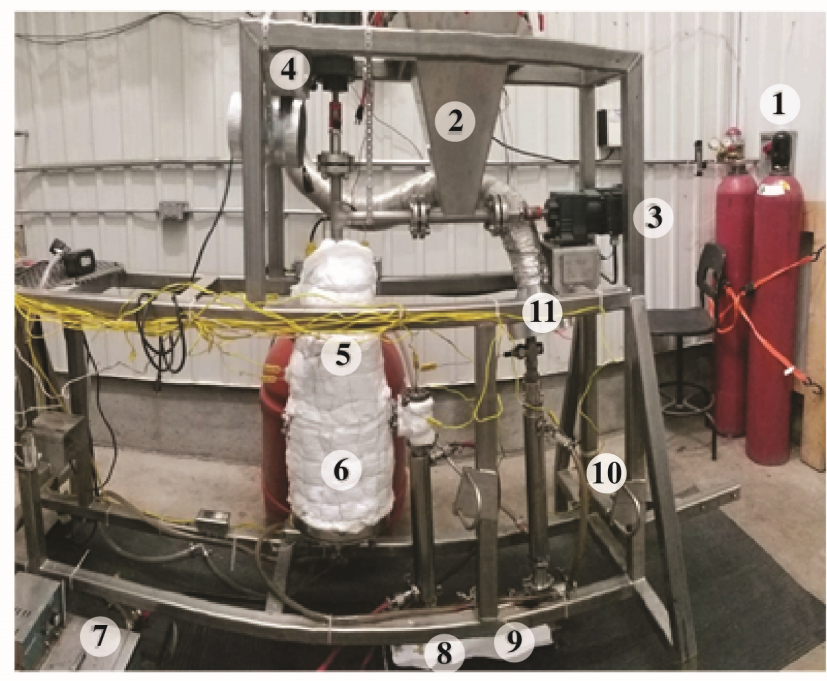

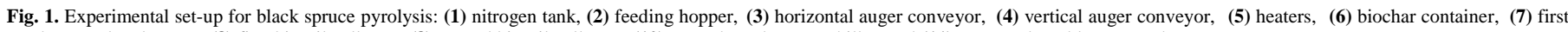
condenser -glycol: water, (8) first bio-oil collector, (8) second bio-oil collector, (10) second condenser - chiller, and (11) non-condensable gases exhaust. 
Table 2.

Experimental factors and levels used in Box-Behnken Design.

\begin{tabular}{lcccc}
\hline & Variable & \multicolumn{3}{c}{ Level } \\
\cline { 3 - 5 } Factors & & -1 & 0 & +1 \\
\hline Temperature of pyrolysis reaction $\left({ }^{\circ} \mathrm{C}\right)$ & $\mathrm{A}$ & 400 & 500 & 600 \\
Solids residence time $(\mathrm{s})$ & $\mathrm{B}$ & 50 & 100 & 150 \\
Nitrogen flowrate $(\mathrm{L} / \mathrm{min})$ & $\mathrm{C}$ & 2.0 & 6.0 & 10 \\
Temperature of first condenser $\left({ }^{\circ} \mathrm{C}\right)$ & $\mathrm{D}$ & 70 & 95 & 120 \\
\hline
\end{tabular}

content was analyzed using the D7579 test method suggested by the ASTM standard. Density at $20^{\circ} \mathrm{C}$ was determined with the D4052 method and $\mathrm{pH}$ using a pH-metre Accumet $\mathrm{AB} 250$.

The analysis of the main components of the oily phase were carried out using an FTIR spectrophotometer Nicolet IS10 (Thermofisher, MA, USA) to determine the functional groups. The spectra were recorded in 32 scans with a wavelength range of $400-4000 \mathrm{~cm}^{-1}$. The chemical components of the oily phase were detected using a gas chromatography-mass spectrometry (GC-MS Agilent $6890 \mathrm{~N}$ ) equipped with an HP-5MS column. The GC was programmed at $45^{\circ} \mathrm{C}$ for $3 \mathrm{~min}$ and it was increased at a rate of $5^{\circ} \mathrm{C} / \mathrm{min}$ up to $260^{\circ} \mathrm{C}$ and finally held at isothermal regime for $5 \mathrm{~min}$. The injector temperature was $260^{\circ} \mathrm{C}$ and the split ratio was set to 50:1. The MS was operated with the ionization energy of $70 \mathrm{eV}$. Helium was used as carrier gas at a flow of $1.0 \mathrm{~mL} / \mathrm{min}$. The bio-oil samples were prepared at 2.5 wt. $\%$ solutions in acetone. Prior to injection, the solutions were filtered through a $0.45 \mu \mathrm{m}$ PTFE filter. Compounds were identified by comparing the chromatographic peaks with the NIST mass spectral library (National Institute of Standards and Technology) (Shen et al., 2015)

\section{Results and Discussion}

\subsection{Analysis of responses for model building}

The effect of temperature of pyrolysis reaction (A), solids residence time (B), nitrogen flow (C), and the temperature of first condenser (D), on the yield of the oily phase $\left(\mathrm{Y}_{1}\right)$ and its water content $\left(\mathrm{Y}_{2}\right)$ were studied. The experimental responses were correlated with the independent variables.

The response of oily phase yield $\left(\mathrm{Y}_{1}\right)$ was fitted to a quadratic model. The results were significant at 0.05 level. Since there were some insignificant terms, the reduction of the full quadratic model was carried out. The reduced model was highly significant with a $\mathrm{p}$-value of $<0.0001$. The actual and significant factors in the reduced model are shown in Equation 1. The most significant factor was the nitrogen flow $(\mathrm{C})$ followed by the temperature of first condenser (D). For the modified quadratic model, the $\mathrm{R}^{2}$ obtained was 0.951 with a
$92.95 \%$ of the total variation in the oily phase yield, attributed to the independent variables, while the Pred. $\mathrm{R}^{2}$ was 0.81 . The high value of $\mathrm{R}^{2}$ for the model indicates that it can be used to explain the variability of the oily phase yield in terms of the independent variables.

Oily phase yield (wt. \%)

$$
\begin{aligned}
& =8.645+0.159 \mathrm{~A}+0.088 \mathrm{~B}-7.4733 \mathrm{C} \\
& -0.0699 \mathrm{D}+0.00826 \mathrm{AC}-0.012 \mathrm{BC} \\
& -0.000208 \times \mathrm{A}^{2}+0.14 \mathrm{C}^{2}
\end{aligned}
$$

The second response studied was the water content $\left(\mathrm{Y}_{2}\right)$ in the oily phase. The effects of the independent variables on the water content were evaluated using a quadratic model, suggested by the software used. Significant terms in the model for water content are nitrogen flow (C) and reactor temperature (A). Like the first step, there were some insignificant terms, so the reduction of the complete quadratic model was carried out For the modified quadratic model, the $\mathrm{R}^{2}$ was 0.88 with a total variation of $83.73 \%$ on the water content, attributed to the independent variables. The reduced model was highly significant with a p-value of $<0.0001$. The equation, in terms of actual values, of the modified quadratic model is shown in Equation 2.

$$
\begin{aligned}
\text { Water content }(\%)= & 68.055-0.2098 \mathrm{~A}+0.2014 \mathrm{~B}+6.39 \mathrm{C} \\
& -0.0515 \mathrm{D}-0.0156 \mathrm{AC}-0.0361 \mathrm{BC} \\
& +0.000284 \mathrm{~A}^{2}+0.2260 \mathrm{C}^{2}
\end{aligned}
$$

Table 3 compares the experimental values of the six most significant results of the 27 experimental results for both responses, considering the minimum and maximum observed points of water content and yield of the oily phase. In addition, the table shows the comparison of the values of the experimental responses and the values calculated using the modified quadratic models for water content and oily phase yield. According to the data shown, the modified models for both responses fit and the values are close to the experimental values. In general, the observed trend is that the higher the nitrogen flow, lower was the yield of the oily phase and the lower is the water content. The point where the highest yield is observed (35.74 wt.\%) coincides with the highest observed value of the water content (49.57 wt.\%), using a minimum flow of nitrogen $(2 \mathrm{~L} / \mathrm{min})$. Conversely, one of the lowest observed values for the oily phase yield (4.99 wt.\%) coincides with the lowest observed value for the water content in the oil (13.24 wt.\%), using the highest nitrogen flow $(10 \mathrm{~L} / \mathrm{min})$. Considering the residence time of the solids, it was observed that by reducing the residence time from 150 $\mathrm{s}$ to $50 \mathrm{~s}$, the water content also decreased from 49.57 to $34.48 \mathrm{wt} . \%$ as well as the yield decreased from 35.74 to 26.52 wt.\%. The same trend was observed when decreasing the pyrolysis temperature from 600 to $400^{\circ} \mathrm{C}$, a

\begin{tabular}{|c|c|c|c|c|c|c|c|}
\hline \multirow[b]{3}{*}{$\begin{array}{l}A \text {-Temp. pyrolysis } \\
\left({ }^{\circ} \mathrm{C}\right)\end{array}$} & \multirow{2}{*}{\multicolumn{3}{|c|}{ Independent variables }} & \multicolumn{4}{|c|}{ Dependent variables } \\
\hline & & & & \multicolumn{2}{|c|}{ Experimental values } & \multicolumn{2}{|c|}{ Calculated values } \\
\hline & $\begin{array}{c}B \text {-Solids residence } \\
\text { time (s) }\end{array}$ & $\begin{array}{c}C-\mathrm{N}_{2} \text { flow } \\
(\mathrm{L} / \mathrm{min})\end{array}$ & $\begin{array}{c}D \text {-Temp. Cond. } 1 \\
\left({ }^{\circ} \mathrm{C}\right)\end{array}$ & $\begin{array}{c}Y_{1} \\
\begin{array}{c}\text { Experimental Oily phase } \\
\text { yield (wt.\%) }\end{array}\end{array}$ & $\begin{array}{c}Y_{2} \\
\begin{array}{c}\text { Experimental Water } \\
\text { content (wt.\%) }\end{array}\end{array}$ & $\begin{array}{c}Y_{1} \\
\underset{(w t . \%)}{\text { Reduced model }}\end{array}$ & $\begin{array}{c}Y_{2} \\
\text { Reduced model } \\
(w \mathrm{t} . \%)\end{array}$ \\
\hline 500 & 150 & 2 & 95 & 35.74 & 49.57 & 32.96 & 46.67 \\
\hline 500 & 50 & 2 & 95 & 26.52 & 34.48 & 26.57 & 33.76 \\
\hline 400 & 100 & 6 & 120 & 12.40 & 29.38 & 12.11 & 30.80 \\
\hline 600 & 100 & 6 & 120 & 13.77 & 26.30 & 12.22 & 26.91 \\
\hline 500 & 100 & 10 & 120 & 3.92 & 22.14 & 4.95 & 20.33 \\
\hline 500 & 150 & 10 & 95 & 4.99 & 13.24 & 5.02 & 13.61 \\
\hline
\end{tabular}
slight decrease was observed in both responses.

Figure 2 shows the effect of nitrogen flow on both responses. The higher the nitrogen flow, the lower the water content as well as the yield obtained

Table 3.

Box Benkhem design with oily phase and water content responses $\left(\mathrm{Y}_{1}, \mathrm{Y}_{2}\right)$.

Please cite this article as: Álvarez-Chávez B.J., Godbout S., Le Roux É., Palacios J.H., Raghavan V. Bio-oil yield and quality enhancement through fast pyrolysis and fractional condensation concepts. Biofuel Research Journal 24 (2019) 1054-1064. DOI: 10.18331/BRJ2019.6.4.2 


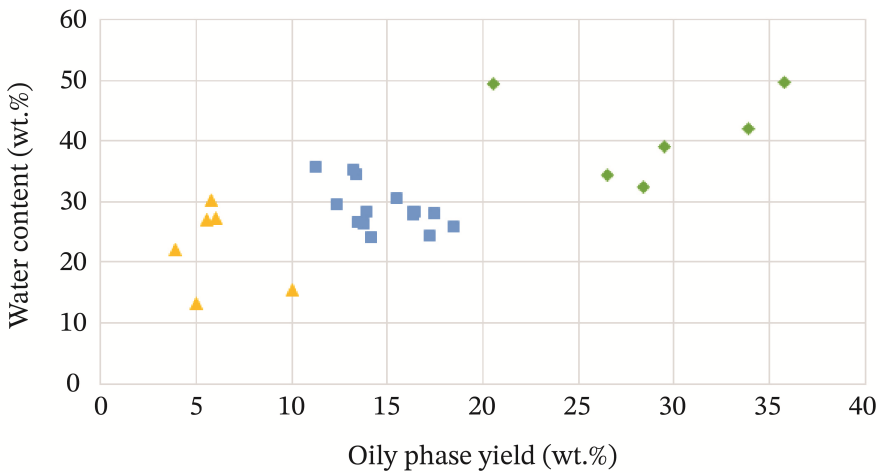

Nitrogen flowrate: $2 \mathrm{~L} / \mathrm{min}$ Nitrogen flowrate: $6 \mathrm{~L} / \mathrm{min}$ Nitrogen flowrate: $10 \mathrm{~L} / \mathrm{min}$ (1)

Fig. 2. Effect of nitrogen flow on the yield and water content of oily phase (Graph plotted using the 27 experiments carried out).

from the oily phase. The carrier flowrate directly affects the condensable vapor residence time. At higher nitrogen flowrate, an intermediate stage of biomass depolymerization is reached during pyrolysis, avoiding secondary cracking reactions. Thus, the vapor residence time should be reduced by increasing nitrogen flow to obtain a pyrolytic liquid with lower water content.

Following the design of the experiment, the desired range was obtained for the water content and the yield at which the oily phase can be produced in the auger reactor. From these results, surface response analysis is applied to optimize the conditions under which pyrolysis must be performed to obtain a bio-oil that can be used in industrial or commercial boilers.

\subsection{Pyrolysis optimization}

The optimization was carried out using the RSM with two criteria, maximizing the yield of the oily phase and minimizing the water content at the same time. The software used suggested the values for the independent variables: $555^{\circ} \mathrm{C}$ for the temperature of pyrolysis reaction (A), $129 \mathrm{~s}$ for the solids residence time (B), $6.9 \mathrm{~L} / \mathrm{min}$ of nitrogen flow (C), and $120^{\circ} \mathrm{C}$ for the temperature in the first condenser (D).

The high nitrogen flow suggested by pyrolysis optimization is intended to decrease the residence time of volatile vapors within the reactor, avoiding secondary cracking reactions. The higher the flow of the carrier gas, the shorter is the residence time. Another strategy applied for the reduction of water in the oily phase is the fractional condensation technique. The temperature suggested by the optimization process was the maximum limit tested $\left(120^{\circ} \mathrm{C}\right)$, considering that a minimum temperature of $80^{\circ} \mathrm{C}$ is recommended, in order to prevent water and light carboxylic acids from condensing in the oily phase. (Papari and Hawboldt, 2018).

The interactions of the most significant factors are plotted at fixed optimal values (Fig. 3). Figures $3 \mathrm{a}$ and b correspond to the oily phase yield response $\left(\mathrm{Y}_{1}\right)$ and Figures $3 \mathrm{c}$ and $\mathrm{d}$ correspond to the water content response $\left(\mathrm{Y}_{2}\right)$. The trend observed in both responses is similar, where the nitrogen flow is the most significant factor. The higher the nitrogen flow, the lower the water content and lower is the oily phase yield. Optimizing the conditions in the pyrolysis process determines the ideal point at which the water content is acceptable, as well as the yield.

At optimal conditions, the expected response of the oily phase yield $\left(\mathrm{Y}_{1}\right)$
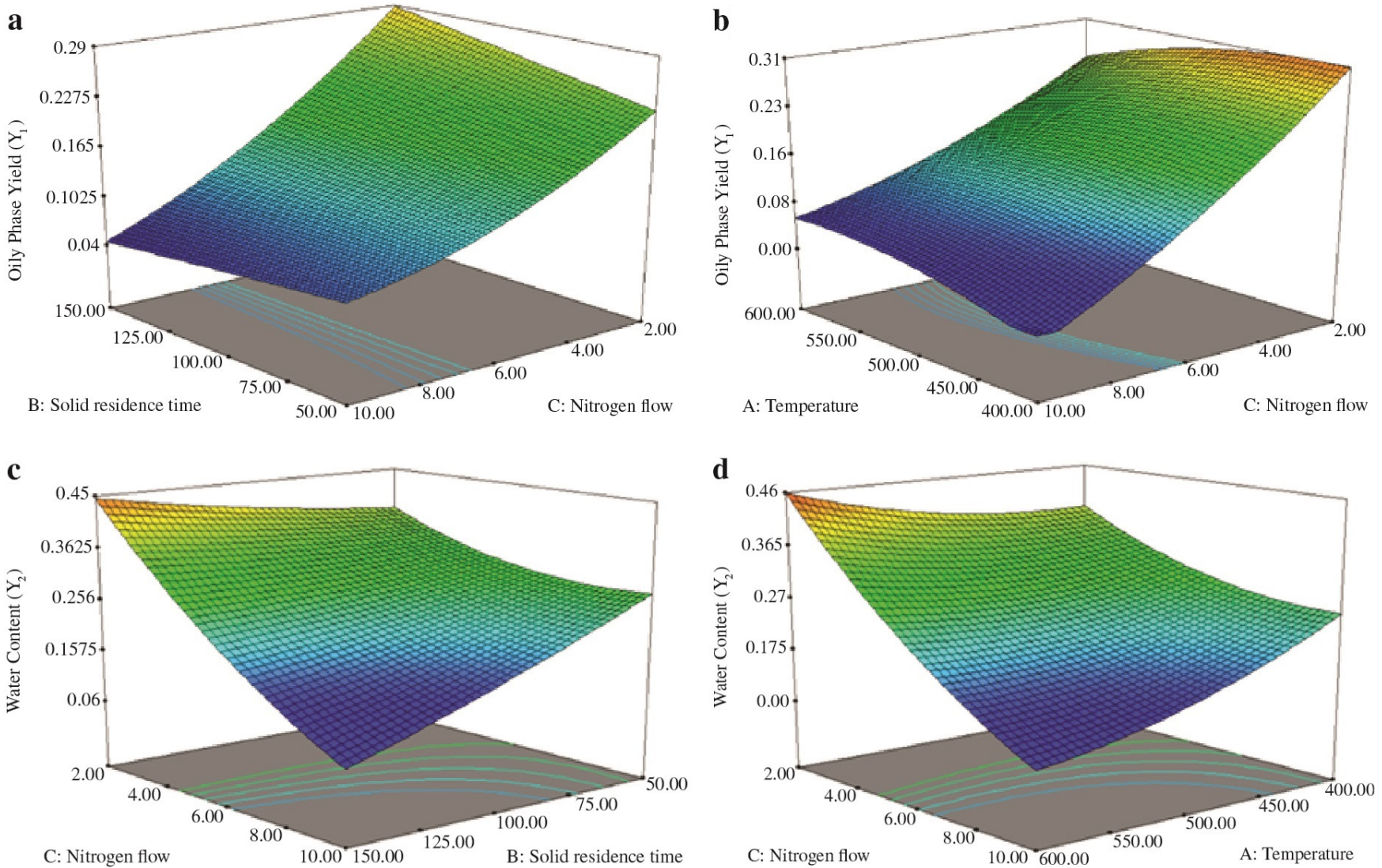

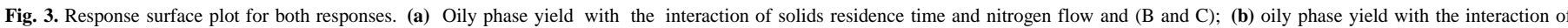
temperature and nitrogen flow (A and C); (c) water content with the interaction B and Cand (d) water content with the interaction $\mathrm{A}$ and $\mathrm{C}$. 
was 12.26 wt.\% and the expected water content $\left(\mathrm{Y}_{2}\right)$ was 19.83 wt.\%. To validate the optimization, three additional experiments were performed. The results were close enough to the predicted values (10.59 wt.\% of oily phase yield and $16.86 \mathrm{wt} . \%$ of water content, as explained in the next section). Thus, the model confirmed the capability of prediction. Besides, according to the ASTM standard D7544-12 (2017), a minimum of $30 \mathrm{wt} . \%$ of water content is required for the use of bio-oil with grade $\mathrm{G}$ or $\mathrm{D}$. Accordingly, the water content of the bio-oil obtained is much lower, making easier for its use in commercial and industrial burners.

The yield of pyrolysis products, under optimum conditions, was $38.61 \mathrm{wt} . \%$ of biochar, 25.39 wt. $\%$ of total liquid, and 36.52 wt.\% of non-condensable gases. The total liquid yield included the two phases obtained in the condensers. The oily phase yield, recovered in the first condenser, was 10.59 wt.\% with a dark brown color (Fig. 4a). The yield in aqueous phase, recovered in the second condenser, was 11.88 wt.\% with an orange color (Fig. $4 \mathrm{~b}$ ).

Some pyrolysis optimization studies have been carried out to evaluate the effect of some operating variables on the yield of bio-oil. Abnisa et al. (2011) employed RSM to pyrolyze $150 \mathrm{~g}$ samples of palm shell waste using a fix-bed reactor. They evaluated the effect of pyrolysis temperature, nitrogen flow, biomass particle size and reaction time on bio-oil yield. The most significant factors obtained were nitrogen flow and reaction temperature. The higher the nitrogen flow, the lower is the yield. However, this study only evaluated oil yield as a single response, resulting in an optimal bio-oil with a water content of 53 wt.\%. Similar studies are published to assess only the effect of fast pyrolysis operating conditions on bio-oil yield (Ellens and Brown, 2012; Kilic et al., 2014). Table 4 shows a comparison among the results of this work and other optimization studies carried out to evaluate the effect of pyrolysis conditions on the yield and chemical composition of pyrolytic oil. The optimization of pyrolysis has been carried out using the RSM based mainly on two experimental designs: Box Behnken Design and Central Composite

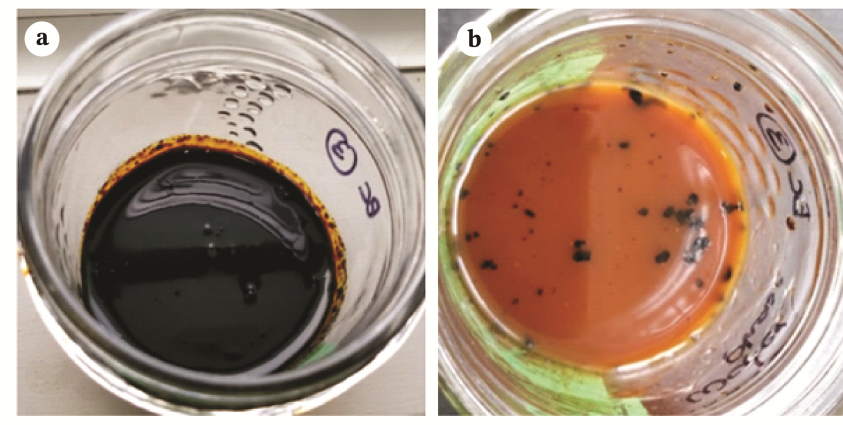

Fig. 4. (a) Oily phase obtained in the first condenser; and (b) Aqueous phase obtained in the second condenser.

Design. Different types of pyrolysis and biomass technologies are presented in the table. However, the aim is to compare the different factors evaluated, their significance and the optimal values of these studies. The main factors chosen to evaluate the effect on bio-oil are reaction temperature, biomass residence time, biomass particle size, and carrier gas flowrate. The optimum temperature range for pyrolysis is in the range of $485-575^{\circ} \mathrm{C}$. Nitrogen flow values and particle size vary widely with the type of technology used, so it could not be compared. However, in most studies, only one response is studied, the yield of the bio-oil, without considering the effect of these factors on the water content or the chemical composition of the bio-oil. Nevertheless, two studies shown are intended for the optimization of pyrolysis for the production of phenolic compounds

Table 4.

Comparison of fast pyrolysis optimization processes.

\begin{tabular}{|c|c|c|c|c|c|}
\hline Characteristics & Current study & Ellens and Brown (2012) & Crespo et al. (2017) & Abas et al. (2018) & Ren et al. (2013) \\
\hline Reactor type & Auger reactor & Free-fall reactor & Laboratory-grade furnace & Microwave-assisted Pyrolysis & Fluidized-bed reactor \\
\hline Biomass & Black spruce (500 g) & Red oak & Wood, A. mangium (10 g) & Oil palm fiber & Larch bark (500 g) \\
\hline Experimental Design & Box Behnken Design & Central composite Design & Box Behnken Design & Central Composite Design & Central Composite Design \\
\hline Factors & $\begin{array}{l}\text { 1. Pyrolysis temperature } \\
\left(400-600^{\circ} \mathrm{C}\right) \\
\text { 2. Solids residence time } \\
(50-150 \mathrm{~s}) \\
\text { 3. Nitrogen flowrate } \\
(2-10 \mathrm{~L} / \mathrm{min}) \\
\text { 4. Temperature of condenser } \\
\left(70-120^{\circ} \mathrm{C}\right)\end{array}$ & $\begin{array}{l}\text { 1. Pyrolysis temperature } \\
\left(450-650^{\circ} \mathrm{C}\right) \\
\text { 2. Biomass particle size } \\
(200-600 \mu \mathrm{m}) \\
\text { 3. Nitrogen flowrate } \\
(1-5 \mathrm{~L} / \mathrm{min}) \\
\text { 4. Biomass feed rate } \\
(1-2 \mathrm{~kg} / \mathrm{h})\end{array}$ & $\begin{array}{l}\text { 1. Pyrolysis temperatura } \\
\left(270-500^{\circ} \mathrm{C}\right) \\
\text { 2. Heating rate } \\
\left(5-15^{\circ} \mathrm{C} / \mathrm{min}\right) \\
\text { 3. Biomass particle size } \\
(0.4-1.38 \mathrm{~mm})\end{array}$ & $\begin{array}{l}\text { 1. Holding time } \\
(11.25-33.75 \mathrm{~min}) \\
\text { 2. Final temperature } \\
\left(350-650^{\circ} \mathrm{C}\right) \\
\text { 3. Absorber loading } \\
\text { (activated carbon: } \\
37.5-112.5 \mathrm{~g})\end{array}$ & $\begin{array}{l}\text { 1. Pyrolysis temperatura } \\
\left(365-534^{\circ} \mathrm{C}\right) \\
\text { 2. Nitrogen flowrate } \\
(23.3-31.7 \mathrm{~L} / \mathrm{min}) \\
\text { 3. Biomass particle size } \\
(0.65-1.56 \mathrm{~mm})\end{array}$ \\
\hline Responses & $\begin{array}{l}\text { a. Bio-oil yield (oily phase) } \\
\text { b. Water content }\end{array}$ & Bio-oil yield & $\begin{array}{l}\text { a. Bio-oil yield } \\
\text { (Water content analyzed } \\
\text { but not optimized) }\end{array}$ & $\begin{array}{l}\text { a. Total phenolic content } \\
\text { b. Bio-oil yield }\end{array}$ & a. Phenols yield \\
\hline Significant Factors & $\begin{array}{l}\text { Bio-oil yield (oily phase) } \\
\text { - Nitrogen flowrate } \\
\text { - Temp. condenser } \\
\text { Water content } \\
\text { - Pyrolysis temperature } \\
\text { - Nitrogen flowrate }\end{array}$ & $\begin{array}{l}\text { - Pyrolysis temperature } \\
\text { - Biomass particle size } \\
\text { - Biomass feed rate }\end{array}$ & $\begin{array}{l}\text { - } \text { Pyrolysis temperature } \\
\text { - } \text { Biomass particle size } \\
\text { - Heating rate }\end{array}$ & $\begin{array}{l}\text { Total phenolic content } \\
\text { - Holding time } \\
\text { - Final temperature } \\
>\text { Bio-oil yield } \\
\text { - Holding time } \\
\text { - Final temperature } \\
\text { - Absorber loading }\end{array}$ & - Biomass particle size \\
\hline Optimal conditions & $\begin{array}{l}\text { 1. } 555^{\circ} \mathrm{C} \\
\text { 2. } 129 \mathrm{~s} \\
\text { 3. } 6.9 \mathrm{~L} / \min \\
\text { 4. } 120^{\circ} \mathrm{C}\end{array}$ & $\begin{array}{l}\text { 1. } 575^{\circ} \mathrm{C} \\
\text { 2. } 300 \mu \mathrm{m} \\
\text { 3. } \text { Not significant } \\
\text { 4. } 2 \mathrm{~kg} / \mathrm{h}\end{array}$ & $\begin{array}{ll}\text { 1. } & 500^{\circ} \mathrm{C} \\
\text { 2. } & 12^{\circ} \mathrm{C} / \mathrm{min} \\
\text { 3. } & 0.46 \mathrm{~mm}\end{array}$ & $\begin{array}{l}\text { 1. } 536.5^{\circ} \mathrm{C} \\
\text { 2. } 23.8 \mathrm{~min} \\
\text { 3. } 86.21 \mathrm{~g} \text { of absorber }\end{array}$ & $\begin{array}{l}\text { 1. } 485^{\circ} \mathrm{C} \\
\text { 2. } 28 \mathrm{~L} / \mathrm{min} \\
\text { 3. } 0.35 \mathrm{~mm}\end{array}$ \\
\hline Optimal responses & $\begin{array}{l}\text { a. Oil yield: } 10.59 \text { wt. } \% \\
\text { b. Water content: } 16.86 \text { wt. } \%\end{array}$ & a. Oil yield: $70 \mathrm{wt} . \%$ & a. Oil yield: 33 wt. $\%$ & $\begin{array}{l}\text { a. Total phenolic content: } \\
26.61 \mathrm{mg} \text { gallic acid/g } \\
\text { b. Bio-oil yield: } 40.66 \mathrm{wt} \%\end{array}$ & $\begin{array}{l}\text { a. Phenols yield: } \\
13.2 \text { wt. } \%\end{array}$ \\
\hline
\end{tabular}


Table 5.

Requirements of the ASTM standard D7544-12 (2017) as well as the characteristics of oily phase from the current study and comparison to other studies.

\begin{tabular}{|c|c|c|c|c|c|c|c|c|c|}
\hline \multirow{2}{*}{ Characteristic } & \multicolumn{2}{|c|}{$\begin{array}{l}\text { ASTM Standard } \\
\text { D 7544-12 }\end{array}$} & \multirow{2}{*}{$\begin{array}{c}\text { Black spruce } \\
\text { (Oily phase) } \\
\text { Current } \\
\text { study }\end{array}$} & \multirow{2}{*}{$\begin{array}{l}\text { Softwood } \\
\text { Papari et al. } \\
\text { (2017) }\end{array}$} & \multirow{2}{*}{$\begin{array}{l}\text { Pine wood } \\
\text { Ingram et } \\
\text { al. (2008) }\end{array}$} & \multirow{2}{*}{$\begin{array}{l}\text { Cotton wood } \\
\text { Hassan et al. } \\
\text { (2009) }\end{array}$} & \multirow{2}{*}{$\begin{array}{l}\text { Corn stalks } \\
\text { Pittman et } \\
\text { al. (2012) }\end{array}$} & \multirow{2}{*}{$\begin{array}{c}\text { Pine Wood } \\
\text { Thangalazhy- } \\
\text { Gopakumar et al. (2010) }\end{array}$} & \multirow{2}{*}{$\begin{array}{l}\text { Japanese cedal } \\
\text { Kato et al. } \\
\text { (2016) }\end{array}$} \\
\hline & Grade G & Grade D & & & & & & & \\
\hline Biomass particle size, $\mathrm{mm}$ & & & $1.0-2.4$ & $<2.0$ & $2.0-4.0$ & $1.0-3.0$ & $0.5-5.0$ & $0.6-0.8$ & 0.7 \\
\hline Biomass moisture content, wt.\% & & & 4.3 & $<1$ & 0 & $8-10$ & $18-20$ & 5.8 & 15.5 \\
\hline Temperature pyrolysis, ${ }^{\circ} \mathrm{C}$ & & & 555 & 450 & 450 & 450 & 450 & 475 & 450 \\
\hline Solids residence time, $\mathrm{s}$ & & & 129 & - & 30 & - & $30-50$ & - & - \\
\hline $\begin{array}{l}\text { Condensation system } \\
\text { (Temperature), }{ }^{\circ} \mathrm{C}\end{array}$ & & & 2: $120-4^{\circ} \mathrm{C}$ & 2: $50-4^{\circ} \mathrm{C}$ & - & - & - & 2: $0^{\circ} \mathrm{C}$ & - \\
\hline Nitrogen flow, L/min & & & 6.9 & - & - & - & - & - & 2 \\
\hline Feed rate, $\mathrm{kg} / \mathrm{h}$ & & & 0.5 & 4.0 & 1.0 & 3.0 & 1.0 & - & $0.3-0.4$ \\
\hline $\begin{array}{l}\text { Gross Heat of Combustion, } \\
\mathrm{MJ} / \mathrm{kg}\end{array}$ & $\geq 15.0$ & $\geq 15.0$ & 18.11 & 16.7 & 21.9 & 21.3 & 22.3 & 18.4 & - \\
\hline Water Content, wt.\% & $\leq 30.0$ & $\leq 30.0$ & 16.86 & 26.0 & 16.0 & 24.3 & 27.3 & 20.3 & 50.0 \\
\hline Solids Content, wt.\% & $\leq 2.5$ & $\leq 0.25$ & 0.18 & 2.4 & 0.2 & - & 2.2 & 0.5 & - \\
\hline Viscosity, $\mathrm{mm}^{2} / \mathrm{s}\left(40^{\circ} \mathrm{C}\right)$ & $\leq 125$ & $\leq 125$ & - & - & $\begin{array}{c}60.9 \\
\left(50^{\circ} \mathrm{C}\right)\end{array}$ & 77.0 & 41.4 & - & - \\
\hline Density at $20^{\circ} \mathrm{C}, \mathrm{kg} / \mathrm{L}$ & $1.1-1.3$ & $1.1-1.13$ & 1.17 & 1.16 & 1.19 & - & 1.17 & 1.14 & 1.13 \\
\hline Sulfur Content, wt.\% & $\leq 0.05$ & $\leq 0.05$ & - & - & - & - & 0.12 & - & - \\
\hline Ash Content, wt.\% & $\leq 0.25$ & $\leq 0.15$ & - & - & - & - & 0.26 & 0.12 & \\
\hline $\mathrm{pH}$ & Report & Report & 2.6 & 2.9 & 3.1 & 3.2 & 3.2 & 2.3 & 2.1 \\
\hline Flash Point, ${ }^{\circ} \mathrm{C}$ & $\geq 45$ & $\geq 45$ & - & - & - & - & - & - & - \\
\hline Pour Point, ${ }^{\circ} \mathrm{C}$ & $\leq-9$ & $\leq-9$ & - & - & - & - & - & - & - \\
\hline
\end{tabular}

(Ren et al., 2013; Abas et al., 2018). The results of this study showed that the optimum temperature is within the published range. Nitrogen flow conditions and biomass residence time are specific to the reactor used. In addition, the current study is a step forward, through the consideration of condensation system conditions.

Overall, there are few optimization studies in the literature and most of them are aimed at the study of oil yield, without considering the water content of the oil. Among the factors considered, no study has been found where the conditions of reaction of pyrolysis with the conditions of oil formation in the condensation system is considered.

\subsection{Chemical composition of bio-oil}

\subsubsection{Physical and chemical properties of oily phase}

The physical and chemical properties of the oily phase are compared to the limits established for grades G and D in the ASTM D7544-12, and to some results available in the literature on pyrolysis of woody biomass (Table 5). Although all studies were conducted using an auger reactor, the configurations and conditions were totally different. Therefore, the properties of the bio-oil can only be used as a reference. Particle size and biomass moisture were similar to all reported studies, while residence time of solids and pyrolysis temperature used in this work are higher. The condensation system used in this work was fractional condensation, combining two condensers at different temperatures. Some of the studies reported also used this type of condensing system, but at lower temperatures. In this case, a higher value for the nitrogen flowrate decreased the residence time of the vapors to produce a higher quality biooil. The properties of the bio-oil obtained in this work meet the requirements of the ASTM D7544-12.

The water content in the bio-oil comes from the initial moisture in the biomass and as a product of reactions during pyrolysis, such as dehydration of cellulose, hemicellulose, and lignin present in the biomass (Ren et al., 2016). Fast pyrolysis in auger reactors generally produces a bio-oil in a 
Table 6.

FTIR analysis of black spruce bio-oil.

\begin{tabular}{llccc}
\hline \multirow{2}{*}{ Functional group } & Compound & Wave number, $\mathbf{~ c m}^{-\mathbf{1}}$ & \multicolumn{2}{c}{ Wave number, $\mathbf{~ m}^{-\mathbf{1}}$} \\
\cline { 3 - 4 } O-H stretching & & $3600-3200$ & Oily phase & Aqueous phase \\
C-H stretching & Water impurities, phenols, alcohols & 3389 & 3389 \\
C=O stretching & Alkanes & $3200-2800$ & 2937 & - \\
& Carboxylic acids, aldehydes, ketones, esters & $1750-1650$ & 1714 & - \\
C=C stretching & Alkenes, aromatics & $1650-1580$ & 1646 & 1639 \\
C-H deformation & Aromatics compounds & $1550-1490$ & 1515 & - \\
C-O stretching & Alkanes & $1470-1350$ & 1362 & - \\
O-H bending & Alcohols, phenols & $1300-950$ & 1050,1266 & 1049 \\
\hline
\end{tabular}

wide range of water content around 16-50 wt.\% due to the different conditions used (Ingram et al., 2008; Pittman et al., 2012; Kato et al., 2016). In this study, water content obtained was $16.8 \mathrm{wt} . \%$, which is one of the lowest reported, as shown in Table 5 . The calorific value of the oily phase obtained was higher than the minimum limit established, within the range of reported data (Hassan et al., 2009; Papari et al., 2017). The solids content in the produced bio-oil is also well below the limit established by the standard, as well as below the results reported in similar studies (Ingram et al., 2008; Pittman et al., 2012; Papari et al., 2017). It has been observed that the use of small particles of raw biomass for pyrolysis leads to the formation of small particles in the oil produced (Moraes et al., 2012; Park et al., 2019). The values obtained for $\mathrm{pH}$ and density are within the range of recent studies carried out (ThangalazhyGopakumar et al., 2010; Papari et al., 2017) .

\subsection{Fourier transfer infrared analysis (FTIR)}

An analysis was made of the composition of the functional groups of the liquid products obtained, both in the oily and in the aqueous phase. From the FTIR spectrum, it is observed that the absorption of the functional groups present in the bio-oil is similar to that of other bio-oils given in the literature (Maguyon and Capareda, 2013; Stas et al., 2014; Nam et al., 2015; David and Kopac, 2018). Table 6 presents the identification of the functional groups detected by the absorbance peaks in both samples. The first peak, within the range $3200-3600 \mathrm{~cm}^{-1}$ corresponds to the $\mathrm{O}-\mathrm{H}$ stretching vibration caused by the presence of water, phenols and alcohols. The dominant peak in the aqueous phase is $\mathrm{O}-\mathrm{H}$ due to the large quantity of water present. The $\mathrm{C}-\mathrm{H}$ stretching vibrations at $3200-2800 \mathrm{~cm}^{-1}$ and the C-H deformation at $1470-1350 \mathrm{~cm}^{-1}$ indicate the presence of alkanes. Only the oily phase registered peaks in this range. The $\mathrm{C}=\mathrm{O}$ stretching vibrations at $1750-1650 \mathrm{~cm}^{-1}$ show the presence of carboxylic acids, aldehydes, ketones, and esters. No peaks were registered for the aqueous phase. The functional group $\mathrm{C}=\mathrm{C}$ corresponds to the presence of alkenes and aromatics compounds, at $1650-1580 \mathrm{~cm}^{-1}$. Both phases of the biooil lead to the functional groups. A higher peak at $1639 \mathrm{~cm}^{-1}$ was detected in the aqueous phase as compared to the oily phase. The $\mathrm{C}=\mathrm{C}$ stretching vibrations, detected at $1550-1490 \mathrm{~cm}^{-1}$, show the presence of aromatics compounds. Only the oily phase detected one peak in this wavelength. C-O stretching at $1300-950 \mathrm{~cm}^{-1}$ suggested the presence of alcohols and phenols. In both phases, the presence of functional groups was detected. Finally, the O-H bending vibration at $900-675 \mathrm{~cm}^{-1}$ corresponds to the polycyclic and substituted aromatic ring, present in both phases of bio-oil.

\subsubsection{Gas chromatography mass spectrometry (GC-MS)}

Normally, the composition of bio-oil is about $16-30 \mathrm{wt} \%$ of water content, detectable organic compounds in GC-MS are about 20-30 wt.\%, water-soluble oligomers about 28-36 wt.\%, and water-insoluble oligomers about 15-23 wt.\% (Kato et al., 2016; Stankovikj et al., 2016; Han et al., 2019). GC-MS analysis was carried out to identify the $20-30$ wt.\% of the organic compounds in the oily phase, produced at optimal conditions. Approximately $85.9 \%$ of the relative content of the total peak area was identified. The identified compounds were classified into the following main chemical categories: carboxylic acids, non-aromatic aldehydes, non-aromatics ketones, benzenediols, furans, phenols, and methoxy-phenols derivatives (Fig. 5). The compounds detected by GC-MS in the oily phase are summarized in Table 7. The chemical group with the highest relative content was that of methoxyphenol derivatives (guaiacols) with a relative content of $27 \%$, where the most abundant compounds are 4-methylguaiacol, guaiacol and trans-isoeugenol with a relative content of $5.51 \%, 5.13 \%$ and $4.49 \%$, respectively. The highest relative content of the identified chemical compound corresponds to levoglucosan with $14.59 \%$, followed by acetic acid with $6.17 \%$ and 1.4-butanodial with $5.60 \%$.

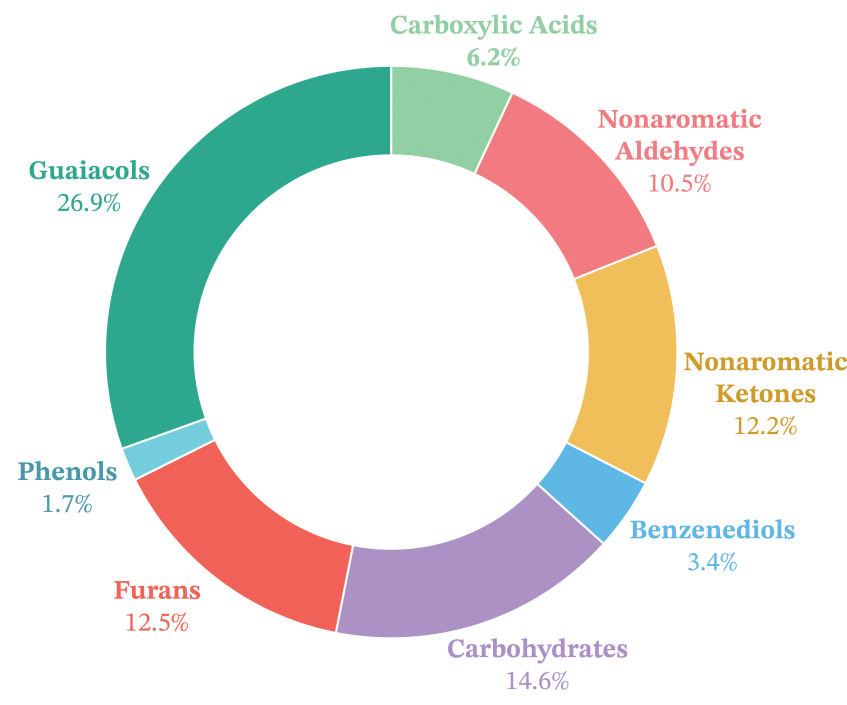

Fig. 5. Relative content of chemical groups identified in the oily phase.

Acetic acid, furfural, hydroxy butanone, and glycolaldehyde compounds are formed during pyrolysis, from the hemicellulose (Azeez et al., 2010 Shen et al., 2015). Levoglucosan is the most important primary derivate from the cellulose, formed during transglycosylation reactions in pyrolysis (Azeez et al., 2010; Shen et al., 2015). Levoglucosan is highly desirable precursor due to its fixed conformation, stereoselectivity, and chemical functionality (Chen et al., 2016). The interest in levoglucosan has increased in recent years for its use as substrate for bio renewable chemicals production in pharmaceutical and polymers sectors (Layton et al., 2011; 
Table 7.

Chemical composition of oily phase produced from black spruce (\% of relative content).

\begin{tabular}{|c|c|c|c|c|c|c|c|}
\hline No. & Retention time & Compounds & $\begin{array}{l}\text { Relative } \\
\text { content }\end{array}$ & No. & Retention time & Compounds & $\begin{array}{l}\text { Relative } \\
\text { content }\end{array}$ \\
\hline 1 & 3.7 & Acetic acid, methyl ester & $6.2 \%$ & 19 & 7.4 & 2(5H)-Furanone & $3.7 \%$ \\
\hline \multicolumn{3}{|c|}{ Total Carboxylic Acids } & $6.2 \%$ & 20 & 9.4 & 4-Methyl-2(5H)-furanone & $0.7 \%$ \\
\hline 2 & 3.9 & 1,4-Butanedial & $5.6 \%$ & 21 & 16.4 & 4-hydroxydihydro-2(3H)-Furanone & $0.5 \%$ \\
\hline 3 & 9.8 & Pentanal (Valeraldehyde) & $0.5 \%$ & 22 & 16.9 & 5-(hydroxymethyl)-furfural & $2.2 \%$ \\
\hline 4 & 11.2 & Hydroxyacetaldehyde (Glycolaldehyde) & $3.4 \%$ & \multicolumn{3}{|c|}{ Total Furans } & $12.5 \%$ \\
\hline 5 & 12.2 & Acetaldehyde & $1.0 \%$ & 23 & 9.6 & Phenol & $0.9 \%$ \\
\hline \multicolumn{3}{|c|}{ Total Nonaromatic Aldehydes } & $10.5 \%$ & 24 & 12.5 & 4-methyl-Phenol (p-cresol) & $0.8 \%$ \\
\hline 6 & 3.6 & 1-Hydroxy-2-butanone & $1.5 \%$ & \multicolumn{3}{|c|}{ Total Phenols } & $1.7 \%$ \\
\hline 7 & 5.8 & 2-Butanone & $0.9 \%$ & 25 & 12.9 & 2-methoxyphenol (guaiacol) & $5.1 \%$ \\
\hline 8 & 6.2 & 1-Acetoxy-2-propanone & $0.7 \%$ & 26 & 16.0 & 4-Methylguaiacol & $5.5 \%$ \\
\hline 9 & 7.7 & 1,2-Cyclopentanedione & $3.5 \%$ & 27 & 18.4 & 4-Ethylguaiacol & $1.7 \%$ \\
\hline 10 & 10.0 & 3,4-Dihydroxy-3-cyclobutene-1,2-dione & $2.5 \%$ & 28 & 19.4 & 4-vinylguaiacol & $2.4 \%$ \\
\hline 11 & 10.9 & 2-Hydroxy-3-methyl-2-cyclopentene-1-one & $2.2 \%$ & 29 & 20.6 & 4-allylguaiacol (eugenol) & $2.3 \%$ \\
\hline 12 & 21.5 & 3-hydroxycyclohexanone & $0.8 \%$ & 30 & 21.6 & Vanillin & $1.4 \%$ \\
\hline \multicolumn{3}{|c|}{ Total Nonaromatic Ketones } & $12.2 \%$ & 31 & 21.9 & $\begin{array}{l}\text { Phenol, 2-methoxy-4-(1-propenyl)- } \\
\text { (Isoeugenol) }\end{array}$ & $0.7 \%$ \\
\hline 13 & 16.1 & 1,2-Benzenediol (catechol) & $2.3 \%$ & 32 & 22.9 & $\begin{array}{l}\text { Phenol, 2-methoxy-4-(1-propenyl)-, (E)- } \\
\text { (trans-Isoeugenol) }\end{array}$ & $4.5 \%$ \\
\hline 14 & 18.7 & 3-Methyl-1,2-benzenediol (3-methylcatechol) & $1.1 \%$ & & & 1-(4-hydroxy-3-methoxyphenyl)-Ethanone & 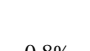 \\
\hline \multicolumn{3}{|c|}{ Total Benzenediols } & $3.4 \%$ & 33 & 23.8 & (Acetoguaiacon) & $0.8 \%$ \\
\hline 16 & 23.6 & $\begin{array}{l}\text { 1,6-Anhydro-.beta-D-glucopyranose } \\
\text { (levoglucosan) }\end{array}$ & $14.6 \%$ & 34 & 24.9 & Benzeneacetic acid, 4-hydroxy-3-methoxy- & $0.7 \%$ \\
\hline \multicolumn{3}{|c|}{ Total Carbohydrates } & $14.6 \%$ & 35 & 27.6 & (Homovanillic acid) & $0.6 \%$ \\
\hline 17 & 5.1 & 2-Furaldehyde (Furfural) & $3.8 \%$ & 30 & 29.3 & 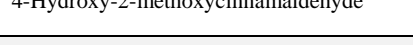 & $1.2 \%$ \\
\hline 18 & 5.7 & 2-Furanmethanol & $1.6 \%$ & \multicolumn{3}{|c|}{ Total Guaiacols (metoxy phenols) } & $26.9 \%$ \\
\hline
\end{tabular}

Nallar and Wong, 2019). The phenolic compounds including guaiacol, 4methylguaiacol, 4-vinylguaiacol, vanillin among others, are derivates from the lignin (Carpenter et al., 2014).

\section{Conclusions}

The technical feasibility of pyrolysis of black spruce was demonstrated by producing a bio-oil whose water and solids content is one of the lowest reported values using auger reactors without the need for additional treatment. Optimization of pyrolysis showed that the most significant factor affecting water content was the flow of nitrogen and the temperature of pyrolysis reaction. Meanwhile, the most significant factors for oily phase yield were the nitrogen flow and temperature of the first condenser. Nitrogen flow was found to be the most significant factor for both responses, as it affects the residence time of the vapors within the pyrolysis and condensers, avoiding secondary cracking reactions. The results revealed an oily phase yield of $10.59 \%$, with a water content of $16.86 \%$. The most abundant chemical group in the oil identified by the GC-MS were methoxyphenols. Levoglucosan was identified as the most abundant compound in the oil phase. For future studies, modification to the condensation system is to be incorporated following the concept of fractional condensation to increase the yield of the oil phase, since the quality is acceptable.

\section{Acknowledgments}

This research was supported by funding from the Mexico's Secretariat of Energy, the National Council on Science and Technology (CONACYTSENER), Bioresource Engineering Department of McGill University and the Research and Development Institute for the Agri-Environment (IRDA), The authors would also like to thank Yvan Gariepy (McGill University), Cédric Morin (IRDA research staff), and master's student Laura MilaSaavedra (UQTR) for their technical assistance.

\section{References}

[1] Abas, F.Z., Ani, F.N., Zakaria, Z.A., 2018. Microwave-assisted production of optimized pyrolysis liquid oil from oil palm fiber. J. Cleaner Prod. 182, 404-413.

[2] Abnisa, F., Daud, W.W., Sahu, J.N., 2011. Optimization and characterization studies on bio-oil production from palm shell by 
pyrolysis using response surface methodology. Biomass Bioenergy. 35(8), 3604-3616.

[3] Anderson, M.J., Whitcomb, P.J., 2016. RSM simplified: optimizing processes using response surface methods for design of experiments. Productivity press.

[4] Auersvald, M., Shumeiko, B., Vrtiska, D., Straka, P., Stas, M., Simacek, P., Blazek, J., Kubicka, D., 2019. Hydrotreatment of straw bio-oil from ablative fast pyrolysis to produce suitable refinery intermediates. Fuel. 238, 98-110.

[5] Azeez, A.M., Meier, D., Odermatt, J., Willner, T., 2010. Fast pyrolysis of African and European lignocellulosic biomasses using Py-GC/MS and fluidized bed reactor. Energy Fuels. 24(3), 20782085.

[6] Brassard, P., Godbout, S., Raghavan, V., Palacios, J., Grenier, M., Zegan, D., 2017. The production of engineered biochars in a vertical auger pyrolysis reactor for carbon sequestration. Energies. 10(3), 15.

[7] Bridgwater, A., Meier, D., Radlein, D., 1999. An overview of fast pyrolysis of biomass. Org. Geochem. 30(12), 1479-1493.

[8] Bridgwater, A.V., 2003. Renewable fuels and chemicals by thermal processing of biomass. Chem. Eng. J. 91(2-3), 87-102.

[9] Cai, W.F., Liu, R.H., He, Y.F., Chai, M.Y., Cai, J.M., 2018. Bio-oil production from fast pyrolysis of rice husk in a commercial-scale plant with a downdraft circulating fluidized bed reactor. Fuel Process. Technol. $171,308-317$.

[10] Carpenter, D., Westover, T.L., Czernik, S., Jablonski, W., 2014. Biomass feedstocks for renewable fuel production: a review of the impacts of feedstock and pretreatment on the yield and product distribution of fast pyrolysis bio-oils and vapors. Green Chem. 16(2), 384-406.

[11] Chen, L., Zhao, J., Pradhan, S., Brinson, B.E., Scuseria, G.E., Zhang, Z.C., Wong, M.S., 2016. Ringlocking enables selective anhydrosugar synthesis from carbohydrate pyrolysis. Green Chem. 18(20), 5438-5447.

[12] Crespo, Y.A., Naranjo, R.A., Quitana, Y.G., Sanchez, C.G., Sanchez, E.M.S., 2017. Optimisation and characterisation of bio-oil produced by Acacia mangium Willd wood pyrolysis. Wood Sci. Technol. 51(5), 11551171.

[13] Daugaard, T.J., Dalluge, D.L., Brown, R.C., Wright, M.M., 2018. Effect of thermophysical properties of heat carriers on performance of a laboratory-scale auger pyrolyzer. Fuel Process. Technol. 176, 182-189.

[14] David, E., Kopac, J., 2018. Pyrolysis of rapeseed oil cake in a fixed bed reactor to produce bio-oil. J. Anal. Appl. Pyrolysis. 134, 495-502.

[15] ÉcoRessources, C.G.D., 2012. INVENTAIRE RÉGI Inventaire régionalisé des biomasses exploitables pour la production de bioénergies au Québec. Ministère des Ressources naturelles, Bureau de l'efficacité et de l'innovation énergétiques, Québec.

[16] Ellens, C.J., Brown, R.C., 2012. Optimization of a free-fall reactor for the production of fast pyrolysis bio-oil. Bioresour. Technol. 103(1), 374-380.

[17] Ferreira, S.L.C., Bruns, R.E., Ferreira, H.S., Matos, G.D., David, J.M., Brandao, G.C., da Silva, E.G.P., Portugal, L.A., Reis, P.S., Souza, A.S., dos Santos, W.N.L., 2007. Box-Behnken design: an alternative for the optimization of analytical methods. Anal. Chim. Acta. 597(2), 179-186.

[18] Fu, P., Bai, X.Y., Yi, W.M., Li, Z.H., Li, Y.J., Wang, L.H., 2017. Assessment on performance, combustion and emission characteristics of diesel engine fuelled with corn stalk pyrolysis biooil/diesel emulsions with $\mathrm{Ce}_{0.7} \mathrm{Zr}_{0.3} \mathrm{O}_{2}$ nanoadditive. Fuel Process. Technol. 167, 474-483.

[19] Gao, W., Zhang, M., Wu, H., 2018. Bed agglomeration during bio-oil fast pyrolysis in a fluidizedbed reactor. Energy Fuels. 32(3), 3608-3613.

[20] Gooty, A.T., Li, D., Briens, C., Berruti, F., 2014. Fractional condensation of bio-oil vapors produced from birch bark pyrolysis. Sep. Purif. Technol. 124, 81-88.

[21] Han, Y., Gholizadeh, M., Tran, C.-C., Kaliaguine, S., Li, C.-Z., Olarte, M., Garcia-Perez, M., 2019. Hydrotreatment of pyrolysis bio-oil: a review. Fuel Process. Technol. 195, 106140.

[22] Hassan, E.M., Yu, F., Ingram, L., Steele, P., 2009. The potential use of whole-tree biomass for biooil fuels. Energy Sources Part A. 31(20), 18291839.

[23] Hosoya, T., Kawamoto, H., Saka, S., 2007. Pyrolysis behaviors of wood and its constituent polymers at gasification temperature. J. Anal. Appl. Pyrolysis. 78(2), 328-336.

[24] Ingram, L., Mohan, D., Bricka, M., Steele, P., Strobel, D., Crocker, D., Mitchell, B., Mohammad, J., Cantrell, K., Pittman, C.U., 2008. Pyrolysis of wood and bark in an auger reactor: physical properties and chemical analysis of the produced bio-oils. Energy Fuels. 22(1), 614625.

[25] Kalargaris, I., Tian, G., Gu, S., 2017. Influence of advanced injection timing and fuel additive on combustion, performance, and emission characteristics of a DI diesel engine running on plastic pyrolysis oil. J. Combust. 2017, 9.

[26] Kato, Y., Enomoto, R., Akazawa, M., Kojima, Y., 2016. Characterization of Japanese cedar bio-oil produced using a benchscale auger pyrolyzer. SpringerPlus. 5(1), 177.

[27] Kilic, M., Putun, E., Putun, A.E., 2014. Optimization of Euphorbia rigida fast pyrolysis conditions by using response surface methodology. J. Anal. Appl. Pyrolysis. 110, 163-171.

[28] Kim, P., Weaver, S., Labbe, N., 2016. Effect of sweeping gas flow rates on temperature-controlled multistage condensation of pyrolysis vapors in an auger intermediate pyrolysis system. J. Anal. Appl. Pyrolysis. 118, 325-334.

[29] Kim, P., Weaver, S., Noh, K., Labbe, N., 2014. Characteristics of biooils produced by an intermediate semipilot scale pyrolysis auger reactor equipped with multistage condensers. Energy Fuels. 28(11), 6966-6973.

[30] Layton, D.S., Ajjarapu, A., Choi, D.W., Jarboe, L.R., 2011. Engineering ethanologenic Escherichia coli for levoglucosan utilization. Bioresour. Technol. 102(17), 8318-8322.

[31] Ly, H.V., Choi, J.H., Woo, H.C., Kim, S.S., Kim, J., 2019. Upgrading bio-oil by catalytic fast pyrolysis of acid-washed Saccharina japonica alga in a fluidized-bed reactor. Renewable Energy. 133, 11-22.

[32] Ly, H.V., Lim, D.H., Sim, J.W., Kim, S.S., Kim, J., 2018. Catalytic pyrolysis of tulip tree (Liriodendron) in bubbling fluidized-bed reactor for upgrading bio-oil using dolomite catalyst. Energy. 162, 564-575.

[33] Maguyon, M.C.C., Capareda, S.C., 2013. Evaluating the effects of temperature on pressurized pyrolysis of Nannochloropsis oculata based on products yields and characteristics. Energy Convers. Manage. 76, 764-773.

[34] Mirkouei, A., Haapala, K.R., Sessions, J., Murthy, G.S., 2017. A review and future directions in techno-economic modeling and optimization of upstream forest biomass to bio-oil supply chains. Renew. Sust. Energy Rev. 67, 15-35.

[35] Montgomery, D.C., 2017. Design and analysis of experiments. John wiley and sons.

[36] Moraes, M.S.A., Georges, F., Almeida, S.R., Damasceno, F.C. Maciel, G.P., Zini, C.A., Jacques, R.A., Caramao, E.B., 2012 Analysis of products from pyrolysis of Brazilian sugar cane straw. Fuel Process. Technol. 101, 35-43.

[37] Nallar, M., Wong, H.W., 2019. Enhanced levoglucosan yields from the copyrolysis of cellulose and high-density polyethylene. ACS Sustainable Chem. Eng. 7(10), 9480-9488.

[38] Nam, H., Capareda, S.C., Ashwath, N., Kongkasawan, J., 2015 Experimental investigation of pyrolysis of rice straw using benchscale auger, batch and fluidized bed reactors. Energy. 93, 23842394.

[39] Oasmaa, A., Fonts, I., Pelaez-Samaniego, M.R., Garcia-Perez, M.E. Garcia-Perez, M., 2016. Pyrolysis oil multiphase behavior and phase stability: a review. Energy Fuels. 30(8), 6179-6200.

[40] Onorevoli, B., Machado, M.E., Polidoro, A.D.S., Corbelini, V.A., Caramao, E.B., Jacques, R.A., 2017. Pyrolysis of residual tobacco seeds: characterization of nitrogen compounds in bio-oil using comprehensive two-dimensional gas chromatography with mass spectrometry detection. Energy Fuels. 31(9), 9402-9407.

[41] Osorio, J., Chejne, F., 2019. Bio-oil production in fluidized bed reactor at pilot plant from sugarcane bagasse by catalytic fast pyrolysis. Waste Biomass Valorization. 10(1), 187-195.

[42] Papari, S., Hawboldt, K., 2018. A review on condensing system for biomass pyrolysis process. Fuel Process. Technol. 180, 1-13.

[43] Papari, S., Hawboldt, K., Helleur, R., 2017. Production and characterization of pyrolysis oil from sawmill residues in an auger reactor. Ind. Eng. Chem. Res. 56(8), 1920-1925.

[44] Park, J.Y., Kim, J.K., Oh, C.H., Park, J.W., Kwon, E.E., 2019 Production of bio-oil from fast pyrolysis of biomass using a pilot- 
scale circulating fluidized bed reactor and its characterization. J. Environ. Manage. 234, 138-144.

[45] Pettersen, R.C., 1984. The chemical composition of wood. Chem. Solid Wood. 207, 57-126.

[46] Pittman, C.U., Mohan, D., Eseyin, A., Li, Q., Ingram, L., Hassan, E.B.M., Mitchell, B., Guo, H., Steele, P.H., 2012. Characterization of bio-oils produced from fast pyrolysis of corn stalks in an auger reactor. Energy Fuels. 26(6), 3816-3825.

[47] Pollard, A.S., Rover, M.R., Brown, R.C., 2012. Characterization of biooil recovered as stage fractions with unique chemical and physical properties. J. Anal. Appl. Pyrolysis. 93, 129-138.

[48] Puy, N., Murillo, R., Navarro, M.V., Lopez, J.M., Rieradevall, J., Fowler, G., Aranguren, I., Garcia, T., Bartroli, J., Mastral, A.M., 2011. Valorisation of forestry waste by pyrolysis in an auger reactor. Waste Manage. 31(6), 1339-1349

[49] Rasul, M., 2016. Clean energy for sustainable development: comparisons and contrasts of new approaches. Academic Press.

[50] Ravindran, H., Thangalazhy-Gopakumar, S., Adhikari, S., Fasina, O., Tu, M., Via, B., Carter, E., Taylor, S., 2015. Production of bio-oil from underutilized forest biomass using an auger reactor. Energy Sources Part. 37(7), 750-757.

[51] Ren, S.J., Ye, X.P., Borole, A.P., Kim, P., Labbe, N., 2016. Analysis of switchgrass-derived bio-oil and associated aqueous phase generated in a semi-pilot scale auger pyrolyzer. J. Anal. Appl. Pyrolysis. 119, 97-103.

[52] Ren, X.Y., Gou, J., Wang, W., Li, Q., Chang, J., Li, B., 2013. Optimization of bark fast pyrolysis for the production of phenol-rich biooil. BioResources. 8(4), 6481-6492.

[53] Shen, D., Jin, W., Hu, J., Xiao, R., Luo, K., 2015. An overview on fast pyrolysis of the main constituents in lignocellulosic biomass to valuedadded chemicals: structures, pathways and interactions. Renew. Sust. Energy Rev. 51, 761-774.

[54] Stankovikj, F., McDonald, A.G., Helms, G.L., Garcia-Perez, M., 2016. Quantification of bio-oil functional groups and evidences of the presence of pyrolytic humins. Energy Fuels. 30(8), 6505-6524.
[55] Stas, M., Kubicka, D., Chudoba, J., Pospisil, M., 2014. Overview of analytical methods used for chemical characterization of pyrolysis bio-oil. Energy Fuels. 28(1), 385-402.

[56] Thangalazhy-Gopakumar, S., Adhikari, S., Ravindran, H., Gupta, R.B., Fasina, O., Tu, M., Fernando, S.D., 2010. Physiochemical properties of bio-oil produced at various temperatures from pine wood using an auger reactor. Bioresour. Technol. 101(21), 8389-8395.

[57] Treedet, W., Suntivarakorn, R., 2018. Design and operation of a low cost bio-oil fast pyrolysis from sugarcane bagasse on circulating fluidized bed reactor in a pilot plant. Fuel Process. Technol. 179, 17 31.

[58] Vithanage, A.E., Chowdhury, E., Alejo, L.D., Pomeroy, P.C., DeSisto, W.J., Frederick, B.G., Gramlich, W.M., 2017. Renewably sourced phenolic resins from lignin bio-oil. J. Appl. Polym. Sci. 134(19), 10.

[59] Westerhof, R.J., Brilman, D.W.F., Garcia-Perez, M., Wang, Z., Oudenhoven, S.R., van Swaaij, W.P., Kersten, S.R., 2011. Fractional condensation of biomass pyrolysis vapors. Energy Fuels. 25(4), 18171829

[60] Westerhof, R.J., Kuipers, N.J., Kersten, S.R., van Swaaij, W.P., 2007. Controlling the water content of biomass fast pyrolysis oil. Ind. Eng. Chem. Res. 46(26), 9238-9247.

[61] Wise, H.G., Dichiara, A.B., Resende, F.L., 2019. Ex-situ catalytic fast pyrolysis of Beetle-killed lodgepole pine in a novel ablative reactor. Fuel. 241, 933-940.

[62] Yang, H.P., Yan, R., Chen, H.P., Lee, D.H., Zheng, C.G., 2007. Characteristics of hemicellulose, cellulose and lignin pyrolysis. Fuel. 86(12-13), 1781-1788.

[63] Yang, H.P., Yan, R., Chen, H.P., Lee, D. H., Zheng, C.G., 2007. Characteristics of hemicellulose, cellulose and lignin pyrolysis. Fuel. 86(12-13), 1781-1788. 